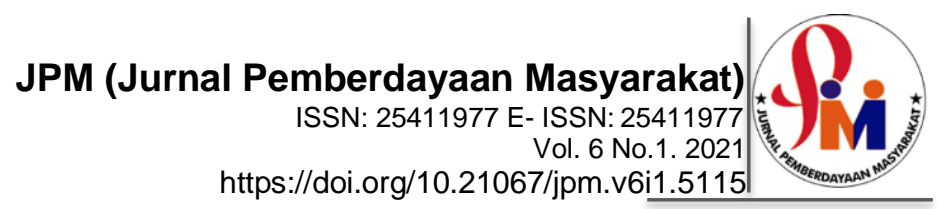

\title{
Kemitraan Bidan dan Ibu Hamil dalam Pencegahan Covid-19
}

\author{
Juana Linda Simbolon ${ }^{1}$, Emilia Silvana Sitompul ${ }^{2}$, Marni Siregar ${ }^{3}$ \\ Poltekkes Kemenkes Medan Prodi D-III Kebidanan Tarutung ${ }^{1,2,3}$ \\ simbolonjuana@gmail.com¹, emilia.sitompul1607@gmail.com², marnisiregar63@gmail.com³
}

\begin{abstract}
COVID-19, a disease that is currently endemic in almost all over the world. COVID-19 affects anyone, including pregnant women and children. The role of midwives in maternal and child health services: ANC service providers are the highest in Indonesia (82.4\%). The challenge of midwifery services during the Covid-19 pandemic: knowledge of mothers and families related to COVID-19 about the dangers of COVID-19 in pregnant women can be a motivation for screening or preventing COVID-19. The aim of the service is to increase knowledge through training midwives and pregnant women about the prevention of COVID-19 and to increase partnerships between midwives and pregnant women through training to be able to socialize the importance of preventing COVID-19 to pregnant women. The method used was conducting pre-tests for midwives and pregnant women, training for midwives on the prevention of COVID-19 in pregnant women, counseling by midwives on prevention of COVID-19, and conducting post-tests. The results obtained by pre-test, the majority of midwives' knowledge was moderate, while the majority of pregnant women had less knowledge. After being given training, the results of the post-test increased the majority of midwives' knowledge was high and the knowledge of pregnant women was high.
\end{abstract}

Keywords: Midwives; Pregnant Women; Covid-19 Knowledge.

\begin{abstract}
Abstrak
COVID-19 penyakit yang sedang mewabah hampir di seluruh dunia. COVID-19 menyerang siapa saja termasuk ibu hamil dan anak-anak. Peran bidan dalam pelayanan Kesehatan ibu dan anak: tenaga pemberi layanan ANC tertinggi di Indonesia $(82,4 \%)$. Tantangan pelayanan kebidanan pada masa pandemi Covid-19: pengetahuan ibu dan keluarga terkait COVID-19 tentang bahaya COVID-19 pada ibu hamil dapat menjadi motivasi dalam melakukan skrining atau pencegahan COVID-19. Tujuan pengabdian meningkatkan pengetahuan melalui pelatihan bidan dan ibu hamil tentang pencegahan COVID-19 dan meningkatkan kemitraan bidan dan ibu hamil melalui pelatihan untuk dapat mensosialisasikan pentingnya pencegahan COVID-19 pada ibu hamil. Metode yang digunakan yaitu melakukan Pre-test kepada Bidan dan Ibu hamil, Pelatihan bidan tentang pencegahan COVID-19 pada ibu hamil, Penyuluhan yang dilakukan bidan tentang pencegahan COVID-19, melakukan Posttest. Hasil yang diperoleh pre-test pengetahuan bidan mayoritas pengetahuan sedang sedangkan pengetahuan ibu hamil mayoritas pengetahuan kurang. Setelah diberikan pelatihan hasil post-test meningkat mayoritas pengetahuan bidan tinggi dan pengetahuan ibu hamil tinggi.
\end{abstract}

Kata Kunci: Bidan; Ibu Hamil; Pengetahuan Covid-19. 


\section{A. PENDAHULUAN}

Bidan merupakan salah satu tenaga kesehatan sebagai garda terdepan dalam pelayanan kesehatan ibu dan anak, KB dan Kesehatan Reproduksi dimasa new normal (Kemenkes, 2020). Peran bidan dalam pelayanan Kesehatan ibu dan anak merupakan tenaga pemberi layanan ANC tertinggi di Indonesia yaitu $(82,4 \%)$ dan persentase tempat pemberi pelayanan ANC tertinggi adalah Bidan Praktek swasta (40,5\%) (Nurjasmi, 2020). Saat ini tercatat jumlah bidan yang terdaftar sebagai Anggota IBI yang memiliki KTA 303.696, Praktek Mandiri Bidan 36.996 dan Bidan delima 18.885. Menurut IBI, 2020 sebanyak 974 dari 9296 laporan yang masuk tanggal 7 Juni 2020 tutup karena APD yang tidak memadai, Isolasi mandiri, ODP dan PDP, dalam perawatan COVID-19, pembatasan jam dan jenis pelayanan serta dilarang keluarga (Handayani, 2020).

Penyebaran kasus Corona virus disease 2019 (COVID-19) berlangsung sangat cepat baik di dunia maupun di Indonesia, COVID-19 dilaporkan pertama kali 31 Desember 2019 adalah penyakit yang sedang mewabah hampir di seluruh dunia saat ini, dengan nama virus Severe Acute Respiratory Syndrome Coronavirus-2 (SARS-COV2) (Sheng, 2020). Data Website pada tanggal 7 Maret 2020 didapatkan kasus komfirmasi sebanyak 90870 dengan total kematian 3112 orang. Pada tanggal 2 Maret 2020, Indonesia melaporkan 2 kasus komfirmasi COVID-19, pada tanggal 11 Maret 2020, WHO sudah menetapkan COVID-19 sebagai Pandemi dan Indonesia sudah melaporkan 27 kasus komfirmasi COVID-19 (RI, 2020). Dashboard kumulatif kasus COVID-19 di Indonesia dari 0203 $=2020 \quad$ s/d sekarang adalah 84882 komfirmasi, sembuh $43268 \quad(50,97 \%)$ meninggal $4010(4,73 \%)$ dan aktif 37598 $(44,29 \%)$. Data terinfeksi COVID-19 di
Sumatera Utara pada tanggal 18 Juli 2020 berada pada urutan ke 8 dari 34 Propinsi di Indonesia dengan jumlah 2923 kasus (Kemenkes Indonesia, 2020). COVID-19 tidak mengenal batas dapat menyerang siapa saja tanpa kecuali, termasuk ibu hamil dan anak-anak.

Menurut PP 61 tahun 2014 pelayanan kesehatan ibu meliputi pelayanan kesehatan masa sebelum hamil, hamil, persalinan dan sesudah melahirkan, pengaturan kehamilan, pelayanan kontrasepsi dan kesehatan seksual dan pelayanan kesehatan sistem reproduksi (Peraturan Pemerintah RI, 2014). Tantangan pelayanan kebidanan pada masa pandemi Covid19 adalah pengetahuan ibu dan keluarga terkait COVID-19 dan pelayanan kesehatan bagi ibu dan bayi baru lahir di era pandemi belum semua bidan tersosialisasi pedoman pelayanan KIA, KB dan Kesehatan Reproduksi di era pandemi, keselamatan bidan dan pasien harus dilindungi sehingga diperlukan penyesuaian pelayanan agar terhindar dari penularan, akses pelayanan kebidanan di era pandemi COVID-19 mengalami perubahan seperti fasilitas kesehatan primer/PMB membatasi pelayanan (Nurjasmi, 2020).

Pengetahuan tentang infeksi COVID-19 dalam hubungannya dengan kehamilan dan janin masih terbatas dan belum ada rekomendasi spesifik untuk penanganan ibu hamil dengan COVID-19 dan beberapa kasus COVID-19, di percaya bahwa ibu hamil memiliki risiko lebih tinggi untuk terjadinya penyakit berat, morbiditas dan mortalitas dibandingkan dengan populasi umum (KemenKes RI, 2020). Puskesmas Sitada- tada terletak di Kecamatan Sipoholon Kabupaten Tapanuli Utara. Puskesmas ini dikenal baik oleh masyarakat yang ada disekitar maupun diluar daerah Kecamatan Sipoholon. Pelayanan disana dirasakan cukup baik oleh para pasien karena Bidan dan perawat yang melayani terkenal baik dan ramah. Kurangnya pemahaman petugas kesehatan terhadap COVID-19 pada ibu hamil menjadi satu permasalahan dalam pemberian dukungan terhadap ibu hamil. Hasil wawancara 
awal dengan beberapa petugas kesehatan, meskipun sudah dilakukan penyuluhan tentang COVID-19 pada ibu hamil belum sepenuhnya tersosialisasikan dengan baik kepada ibu hamil maupun keluarga. Oleh karena itu perlu adanya kemitraan antara bidan dan ibu hamil sehingga peningkatan pengetahuan dan pemahaman masyarakat tentang pencegahan COVID-19 pada ibu hamil agar kesadaran tentang bahaya COVID-19 pada ibu hamil dapat menjadi motivasi dalam melakukan skrining atau pencegahan COVID-19 (Munafiah \& Wulandari, 2020).

Berdasarkan hal tersebut maka penulis melaksanakan salah satu Tri Darma Perguruan Tinggi dalam rangka membantu upaya keberhasilan pencegahan kasus Covid 19 pada kehamilan melalui pelatihan Bidan tentang bagaimana pencegahan COVID-19 pada ibu hamil. Kegiatan pengabdian pada masyarakat ini memiliki beberapa tujuan antara lain:

a. Meningkatkan pengetahuan melalui pelatihan bidan dan ibu hamil tentang pencegahan COVID-19.

b. Meningkatkan kemitraan bidan dan ibu hamil melalui pelatihan untuk dapat mensosialisasikan pentingnya pencegahan COVID-19 pada ibu hamil.

\section{B. PELAKSAAAN DAN METODE}

Menurut UU Kebidanan No 4 tahun 2019 Bidan adalah seorang perempuan yang telah menyelesaikan program pendidikan Kebidanan baik di dalam negeri maupun diluar negeri yang diakui secara sah oleh Pemerintah Pusat dan telah memenuhi persyaratan untuk melakukan praktik Kebidanan. Pelayanan Kebidanan adalah suatu bentuk pelayanan profesional yang merupakan bagian integral dari sistem pelayanan kesehatan yang diberikan oleh bidan secara mandiri, kolaborasi, dan/atau rujukan. Tugas dan wewenang bidan adalah Pelayanan kesehatan ibu, Pelayanan Kesehatan anak, Pelayanan kesehatan reproduksi perempuan dan KB, Pelaksanaan tugas berdasarkan pelimpahan wewenang, Pelaksanaan tugas dalam keadaan keterbatasan tertentu yang dilakukan di tempat Praktik Mandiri Bidan dan atau Fasilitas Pelayanan Kesehatan lainnya, harus dilakukan sesuai dengan kompetensi dan kewenangan serta mematuhi kode etik, standart profesi, standart pelayanan dan standart operasional.

Kemitraan bidan dan ibu hamil adalah suatu bentuk kerja sama yang saling menguntungkan atas dasar prinsif keterbukaan dan kepercayaan. Kerjasama dapat membantu meringankan pekerjaan bidan sehingga kasus COVID-19 dapat dicegah baik pada petugas kesehatan dalam hal ini bidan dan ibu hamil. Berdasarkan masalah yang ditemukan upaya yang dilakukan untuk memecahkan masalah yang agar COVID-19 dapat dicegah dalam hal ini ada berbagai cara yang akan dilakukan. Adapun upaya-upaya yang dilakukan tersebut yaitu:

1. Melakukan Pre-test kepada Bidan dan Ibu hamil

2. Pelatihan bidan tentang pencegahan COVID-19 pada ibu hamil

3. Penyuluhan yang dilakukan bidan tentang pencegahan COVID-19

4. Melakukan Post-test

Kegiatan pengabdian masyarakat yang dilaksanakan merupakan rangkaian kegiatan yang disusun secara terencana disesuaikan dengan situasi dan kondisi yang ada. Kegiatan ini diawali dengan melakukan survey awal pada bulan Oktober 2020 ke Puskesmas Sitada-tada. Survey awal ini dilakukan untuk: a) Mendapatkan izin dari pihak atau kepala Puskesmas Sitada-tada menetukan jumlah sasaran, b) Melihat situasi dan kondisi serta, c) Mengetahui sarana dan prasarana yang ada untuk mendukung pelaksanaan kegiatan, dan d) 
Menentukan waktu pelaksanaan kegiatan agar sesuai dengan situasi bidan dan ibu hamil di masyarakat.

Langkah selanjutnya adalah membuat dan menyerahkan surat permohonan izin pelaksanaan kegiatan. Sebelum pelaksanaan kegiatan maka pelaksana mempersiapkan hal-hal yang diperlukan untuk pelaksanaan kegiatan berupa susunan acara untuk pelaksanaan pelatihan, pengisian daftar hadir, persiapan materi pelatihan bidan tentang pencegahan COVID-19 pada kehamilan dan mempersiapkan alat dan bahan yang akan digunakan.

Metode Pelaksanaan Kegiatan terdiri atas beberapa tahap meliputi: Tahap Perencanaan yaitu dilakukan dengan mendata bidan yang ada di Puskesmas Sitada-tada Kecamatan Sipoholon sebanyak 20 orang dan melakukan survey ibu hamil sebanyak 28 orang. Tahap Persiapan dilakukan dengan survei awal, Pemantapan dan penentuan lokasi dan sarana, dan penyusunan bahan materi. Tahap Pelaksanaan terdiri atas beberapa tahap yaitu:

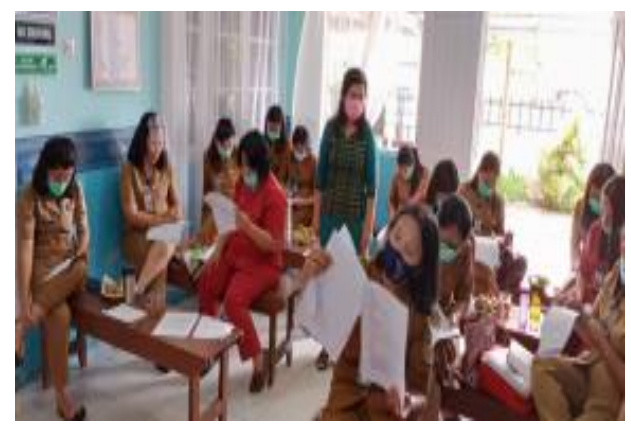

Gambar 1. Kegiatan Pre Test pada Bidan

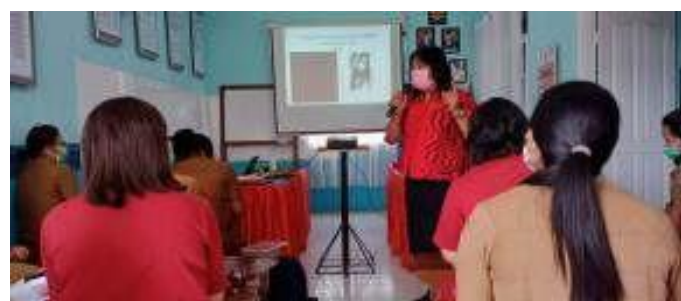

Gambar 2. Kegiatan Edukasi pada Bidan pada ibu hamil
JPM (Jurnal Pemberdayaan Masyarakat)

ISSN: 25411977 E- ISSN: 25411977

Vol. 6 No.1. 2021
$07 / j p m . v 6 i 1.5115$

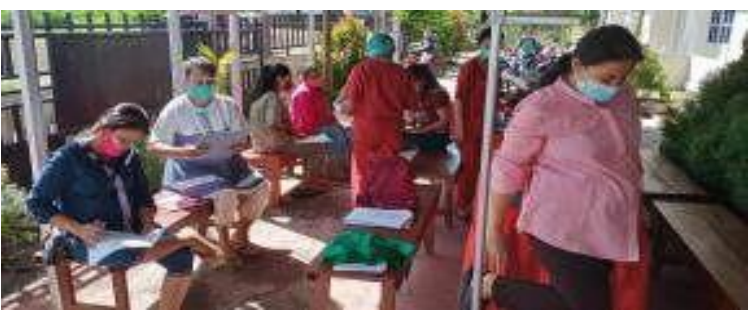

Gambar 3. Edukasi kepada Ibu hamil

Post Test/Evaluasi adapun untuk mengetahui kemampuan pengetahuan Bidan dan ibu Hamil tentang pencegahan COVID-19. Waktu dan Tempat Pelaksanaan

Pelaksanaan kegiatan pengabdian masyarakat ini dilakukan di Puskesmas Sitadatada sebagai berikut: Tanggal 2 November 202013 November 2020

\section{HASIL DAN PEMBAHASAN}

Menurut UU Kebidanan No 4 tahun 2019 Bidan adalah seorang perempuan yang telah menyelesaikan program pendidikan Kebidanan baik di dalam negeri maupun diluar negeri yang diakui secara sah oleh Pemerintah Pusat dan telah memenuhi persyaratan untuk melakukan praktik Kebidanan. Pelayanan Kebidanan adalah suatu bentuk pelayanan profesional yang merupakan bagian integral dari sistem pelayanan kesehatan yang diberikan oleh bidan secara mandiri, kolaborasi, dan/atau rujukan. Tugas dan wewenang bidan adalah Pelayanan kesehatan ibu, Pelayanan Kesehatan anak, Pelayanan kesehatan reproduksi perempuan dan $\mathrm{KB}$, Pelaksanaan tugas berdasarkan pelimpahan wewenang, Pelaksanaan tugas dalam keadaan keterbatasan tertentu yang dilakukan di tempat Praktik Mandiri Bidan dan atau Fasilitas Pelayanan Kesehatan lainnya, harus dilakukan sesuai dengan kompetensi dan kewenangan serta mematuhi kode etik, standart profesi, standart pelayanan dan standart operasional.

Kemitraan bidan dan ibu hamil adalah suatu bentuk kerja sama yang saling menguntungkan atas dasar prinsip keterbukaan dan kepercayaan. Kerjasama dapat membantu 
meringankan pekerjaan bidan sehingga kasus COVID-19 dapat dicegah baik pada petugas kesehatan dalam hal ini bidan dan ibu hamil. Pelayanan ANC pada ibu hamil adalah $10 \mathrm{~T}$, yang dilaksanakan minimal 6 x selama masa kehamilan meliputi pemeriksaan dokter $1 \mathrm{x}$ pada trisemester 1 untuk screning kesehatan ibu seutuhnya, 2x trisemester 1, $1 \mathrm{x}$ trisemester 2, 3 kali trisemester 3 yang meliputi 2 kali oleh bidan, 1 kali pemeriksaan oleh dokter untuk deteksi komplikasi kehamilan/mempersiapkan rujukan persalinan jika perlu. Prinsip-prinsip manajemen COVID-19 pada kehamilan meliputi isolasi awal, prosedur pencegahan infeksi sesuai standar, terapi oksigen, hindari kelebihan cairan, pemberian antibiotik empiris (mempertimbangkan risiko sekunder akibat infeksi bakteri), pemeriksaan SARSCoV-2 dan pemeriksaan infeksi penyerta yang lain, pemantauan janin dan kontraksi uterus, ventilasi mekanis lebih dini apabila terjadi gangguan pernapasan yang progresif, perencanaan persalinan berdasarkan pendekatan individual/indikasi obstetri, dan pendekatan berbasis tim dengan multidisipin.

Panduan Pelayanan ANC oleh bidan pada masa pandemi COVID adalah menerapkan isi buku KIA di rumah segera ke fasilitas pelayanan kesehatan jika ada keluhan/tanda bahaya, membuat janji melalui telepon/WA, melakukan pengkajian komprehensif sesuai standart dan kewaspadaan COVID-19 dengan berkoordinasi dengan RT/RW/Kades tentang status ibu (ODP/PDP, Covid +), ANC dilakukan sesuai standart (10T) dengan APD level 1, melakukan skrining faktor resiko, jika ditemukan faktor resiko rujuk sesuai standart, ibu hamil, pendamping dan tim kesehatan yang bertugas menggunakan masker dan menerapkan protokol pencegahan covid-19; menunda kelas ibu hamil dilakukan secara online; Konsultasi kehamilan, KIE dan Konseling dapat dilakukan secara online.

Upaya pencegahan penyebaran COVID19 dan Bayi Baru Lahir adalah meningkatkan sosialisasi informasi dan edukasi pencegahan penularan COVID-19 melalui media elektronik serta peran tokoh masyarakat; mendorong pelayanan kesehatan ibu dan bayi baru lahir sesuai prinsip pencegahan COVID 19 dan pemanfaatan Telemedicine untuk pelayanan KIA. Penyelenggaraan Posyandu hanya diperuntukkan di daerah resiko rendah dan tanpa kasus COVID-19 dengan tetap sesuai kaidah yang telah ditetapkan serta diperuntukkan hanya untuk pelayanan imunisasi dan balita dengan masalah gizi.

Pemeriksaan Kehamilan meliputi ANC pertama yang dilakukan pada ibu hamil trimester 1 untuk dilakukan skrining kesehatan (termasuk HIV, Sifilis, Hepatitis, dan Malaria) untuk mendeteksi secara dini faktor risiko dan penyulit. Untuk ibu hamil yang sehat, tidak memiliki keluhan dan tanda bahaya, ANC pada trisemester kedua di tunda, ANC pada trisemester ketiga harus dilakukan untuk menyiapkan proses persalinan, minimal 1 bulan sebelum taksiran persalinan. Tablet Tambah Darah tetap diberikan kepada ibu hamil yang sehat, bagi ibu hamil dengan status PDP terkonfirmasi diberikan dengan pertimbangan dokter yang merawat, Kelas ibu hamil ditunda atau dilaksanakan secara online. Memberikan Pelayanan kesehatan bagi ibu dan bayi baru lahir dengan menerapkan protokol kesehatan sesuai pedoman bagi Ibu Hamil, Bersalin, Nifas dan Bayi Baru Lahir di Era Pandemi Covid-19, Kelas ibu hamil online, P4K melalui media komunikasi, menganjurkan persalinan di fasilitas pelayanan kesehatan sesuai indikasi.

Ibu hamil harus melakukan langkah pencegahan yang sama seperti orang lain untuk menghindari infeksi COVID-19, dapat melindungi diri dengan cara: rajin mencuci tangan dengan menggunakan sabun dan air bersih yang mengalir, atau cairan antiseptik 
https://doi.org/10.21067/jpm.v6i1.5115

Tabel 1. Tingkat Pengetahuan Bidan Pre Test

berbahan dasar alkohol, Menjaga jarak dengan orang lain, setidaknya 1 meter, terutama dengan orang yang sedang batuk atau bersin, Menghindari menyentuh mata, hidung, dan mulut, menjaga kebersihan pernapasan. Tutup mulut dan hidung saat batuk atau bersin dengan siku yang terlipat atau tisu. Lalu segera buang tisu bekas tersebut ke dalam tempat sampah tertutup. Segera mencari pertolongan medis jika demam, batuk, atau kesulitan bernapas. Hubungi via telepon sebelum pergi ke fasilitas pelayanan kesehatan, dan mengikuti arahan dari dinas kesehatan setempat Ibu hamil dan ibu yang baru melahirkan termasuk mereka yang terjangkit COVID-19 harus menjalani perawatan kesehatan rutin seperti biasanya. Protokol dan kelayakan pemeriksaan dapat berbeda, tergantung dari daerah, WHO merekomendasikan bahwa ibu hamil dengan gejala COVID-19 harus diprioritaskan untuk menjalani pemeriksaan. Jika mereka terjangkit COVID-19 mungkin membutuhkan perawatan khusus. COVID-19 dapat ditularkan dari ibu ke bayi yang belum lahir atau bayi yang baru lahir, belum diketahui apakah seorang ibu hamil yang terjangkit COVID-19 dapat menularkan virus tersebut ke janin.

Hasil menunjukkan bahwa bagaimana pencegahan Covid-19 belum sepenuhnya tersosialisasi baik kepada bidan terutama kepada ibu hamil. Para Ibu hamil masih banyak mengabaikan pencegahan penyebaran Covid-19. Tahap Pemberian Pendidikan Kesehatan Kepada Bidan

Bidan yang berpartisipasi pada kegiatan pengabdian masyarakat ini terdiri dari 20 orang, mereka merupakan bidan desa yang bertugas di Puskesmas Sitada-tada. Pengabdian ini dilaksanakan pada tanggal 213 sampai November 2020. Hasil kegiatan pendidikan kesehatan sebelum dan sesudah pelaksanaan pegabdian masyarakat adalah sebagai berikut: dan Post Test

\begin{tabular}{l|c|c}
\multicolumn{2}{c}{ dan Post Test } \\
$\begin{array}{l}\text { Tingkat } \\
\text { Pengetahuan }\end{array}$ & $\begin{array}{c}\text { Pre } \\
\text { Test }\end{array}$ & $\begin{array}{c}\text { Post } \\
\text { Test }\end{array}$ \\
\hline Pengetahuan Kurang & 0 & 0 \\
\hline Pengetahuan Sedang & 20 & 0 \\
\hline Pengetahuan Baik & 0 & 20 \\
\hline
\end{tabular}

Setelah dilakukan pendidikan kesehatan kepada bidan terkait pendidikan Pencegahan Covid-19 dalam hubungannya dengan kehamilan dan janin maka selanjutnya adalah pemberian pendidikan kesehatan oleh Bidan kepada ibu hamil. Ibu hamil yang berpartisipasi pada kegiatan pengabdian masyarakat ini terdiri dari 28 orang, mereka merupakan ibu hamil yang berada di wilayah kerja Puskesmas Sitadatada. Kegiatan ini dilaksanakan pada tanggal 11 sampai 13 November 2020.

Tabel 2. Tingkat Pengetahuan Ibu Hamil Pre Test dan Post Test

\begin{tabular}{lll}
\hline $\begin{array}{l}\text { Tingkat } \\
\text { Pengetahuan }\end{array}$ & Pre Test & Post Test \\
\hline $\begin{array}{l}\text { Pengetahuan } \\
\text { Kurang }\end{array}$ & 19 & 0 \\
\hline $\begin{array}{l}\text { Pengetahuan } \\
\text { Sedang }\end{array}$ & 9 & 4 \\
\hline $\begin{array}{l}\text { Pengetahuan } \\
\text { Baik }\end{array}$ & 0 & 24 \\
\hline
\end{tabular}

Tahap Evaluasi

Kegiatan evaluasi dilakukan pada bagian akhir rangkaian kegiatan ini baik kepada bidan maupun kepada ibu hamil dengan cara menggali sejauh mana informasi tentang pencegahan Covid-19 yang dapat diterima oleh peserta. Kegiatan evaluasi ini dilakukan melalui posttest, adapun hasilnya disajiakan pada tabel berikut ini. 


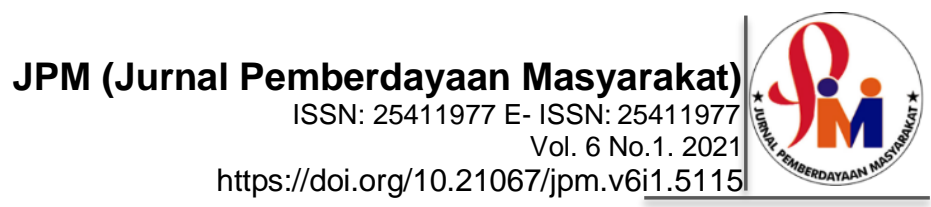

Tabel 3. Gambaran pengetahuan Bidan dan Ibu hamil tentang Pecegahan Covid-19 berhubungan dengan kehamilan dan janin setalah Pendidikan kesehatan dilakukan

\begin{tabular}{lcccc}
\hline & \multicolumn{4}{c}{ Peserta } \\
\cline { 2 - 5 } Karakteristik & \multicolumn{2}{c}{ Bidan } & \multicolumn{3}{c}{ Ibu hamil } \\
\cline { 2 - 5 } & $\mathrm{n}=20$ & $\%$ & $\mathrm{n}=28$ & $\%$ \\
& & & & \\
\hline Pengetahuan & & & & \\
a. Tinggi & 20 & $100 \%$ & 24 & $86 \%$ \\
b. Sedang & 0 & $0 \%$ & 6 & $14 \%$ \\
c. Rendah & 0 & $0 \%$ & 0 & $0 \%$ \\
\hline
\end{tabular}

\section{PENUTUP}

\section{Simpulan}

Kegiatan pendidikan kesehatan yang dilakukukan kepada bidan dan ibu hamil yang dilakukan di puskesmas Sitada-tada sangat penting dan bermanfaat untuk meningkatkan kesadaran bidan dan ibu hamil akan bahaya Covid-19 dikarenakan bahaya-bahaya yang akan dialami ibu terkait kehamilan dan janinnya.

\section{Saran}

\section{Bagi Bidan}

Agar selalu update ilmu terkait Covid-19 dan selalu melakukan pencegahan penularan Covid-19 dengan cuci tangan dengan sabun dan air mengalir sedikitnya selama 20 detik, gunakan hand sanitizer berbasis alkohol yang setidaknya mengandung alkohol 70\%, sebaiknya hindari kontak dengan orang yang sedang sakit. Gunakan masker medis saat sakit. Tetap tinggal di rumah saat sakit atau segera ke fasilitas kesehatan yang sesuai, jangan banyak beraktivitas di luar. Tutupi mulut dan hidung saat batuk atau bersin dengan tissue. Menggunakan masker medis adalah salah satu cara pencegahan penularan penyakit saluran napas, termasuk infeksi COVID-19. Rajin mencari informasi yang tepat dan benar mengenai COVID-19 di media sosial terpercaya.

2. Bagi Ibu Hamil

Untuk pemeriksaan hamil pertama kali, buat janji dengan dokter, bidan agar tidak menunggu lama. Selama perjalanan ke fasyankes tetap melakukan pencegahan penularan COVID-19 secara umum. Memeriksakan kondisi dirinya sendiri dan gerakan janinnya, senantiasa menjaga kesehatan dengan mengonsumsi makanan bergizi seimbang, menjaga kebersihan diri dan tetap mempraktikan aktivitas fisik berupa senam ibu hamil/yoga/pilates/aerobic/ peregangan secara mandiri dirumah agar ibu tetap bugar dan sehat. Ibu hamil tetap minum tablet tambah darah sesuai dosis yang diberikan oleh tenaga kesehatan.

\section{Ucapan Terima Kasih}

Terimakasih kepada Kepala Puskesmas Sitada-tada, Bidan Desa serta Ibu Hamil yang ikut serta dalam kegiatan pengabdian ini.

\section{E. DAFTAR PUSTAKA}

Handayani, D. (2020). Penyakit Virus Corona 2019. Jurnal Respirologi Indonesia.

Kemenkes. (2020). Stigma Berkontribusi Terhadap Tingginya Angka Kematian COVID-19. Covid19.go.id.

Kemenkes Indonesia. (2020). Buku Pedoman Pemberdayaan masyarakat dalam pencegahan COVID-19. In Kementerian Kesehatan RI, Direktorat Jenderal Kesehatan Masyarakat, Direktorat Promosi Kesehatan dan Pemberdayaan Masyarakat.

Kemenkes RI, 2020. (2020). Protokol Kesehatan Bagi Masyarakat di Tempat dan Fasilitas Umum Dalam Rangka Pencegahan dan Pengendalian Corona Virus Disease 2019 (Covid-19).

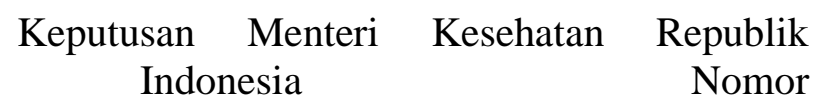


HK.01.07/MENKES/382/2020

tentang Protokol Kesehatan Bagi

Masyarakat di Tempat dan Fasilitas

Umum dalam rangka Pencegahan dan Pengendalian COVID-19, Peraturan Menteri Kesehatan Republik Indonesia (2020).

Munafiah, D., \& Wulandari, R. P. (2020). Semon (Seminar Online Nasional) Kebidanan Asuhan Psikis Dan Fisik Pada Persalinan Normal Oleh Praktik Bidan Mandiri (Pmb) di Masa Covid-19. Jurnal Pengabdian Masyarakat Sasambo. https://doi.org/10.32807/jpms.v2i1.6 00 .

Nurjasmi, E. (2020). Situasi Pelayanan Kebidanan pada Masa Pandemi COVID-19. Ibi.or.id.

Peraturan Pemerintah RI. (2014). Peraturan Pemerintah Republik Indonesia Nomor 61 Tahun 2014 Tentang Kesehatan Reproduksi. Implementation Science.

RI, K. (2020). Keputusan Menteri Kesehatan Republik Indonesia Nomor Hk.01.07/Menkes/382/2020 Tentang Protokol Kesehatan Bagi Masyarakat Di Tempat Dan Fasilitas Umum Dalam Rangka Pencegahan Dan Pengendalian Corona Virus Disease 2019 (Covid-19).

Sheng, W. H. (2020). Coronavirus disease 2019 (covid-19). Journal of Internal Medicine of Taiwan. https://doi.org/10.6314/JIMT.20200 4_3 1(2).01. 